\title{
KARAKTERISTIK MEMBRAN KOMPOSIT BERBASIS KITOSAN/PVA TERMODIFIKASI LEMPUNG DARI BABAKAN MADANG BOGOR
}

\author{
Tria Kharisma ${ }^{1)}$, Nina Ariesta ${ }^{1{ }^{*}}$ dan Dian Arrisujaya ${ }^{1)}$ \\ ${ }^{1)}$ Program Studi Kimia, Fakultas MIPA, Universitas Nusa Bangsa Bogor \\ Jl. KH. Sholeh Iskandar Km.4 Tanah Sareal Bogor, 16166 \\ "e-mail: ariestanina14@ggmail.com
}

\begin{abstract}
Characteristics of Clay Modified/Chitosan/PVA Based Composite Membranes From Babakan Madang Bogor
\end{abstract}

\begin{abstract}
The use of natural polymers as membranes of DMFCfrom chitosan was developed because it is more environmentally friendly and has high thermal stability, but the proton conductivity is low. The Clay from Babakan Madang, which contained of $\mathrm{SiO}_{2} 50 \%$ was expected to increase proton conductivity and improve the characteristics of the polymer membrane. Chitosan / PVA based membrane synthesis was carried out by adding clay of varied weight variations of 0.3, 0.6 and $0.9 \mathrm{~g}$. The spectra of membranes investigated by FT-IR confirmed the presence of functional groups from chitosan/PVA/clay. Morphological analysis using SEM showed that there were granules of clay dispersed on the membrane. The determination of membran conductivity using EIS showed that the membrane with the addition of $0.6 \mathrm{~g}$ of clay was the highest of proton conductivity value, it was $6.96 \times 10^{-7} \mathrm{~S} / \mathrm{cm}$. The water swelling data of the three membranes tended to be high, with the smallest value of $56.69 \%$ on the membrane with the addition of 0.9 grams of clay. The methanol uptake data found that the conductivity of membrane with the addition of 0.6 grams of clay was $346.11 \%$.
\end{abstract}

Keywords: ion exchange membran, chitosan, fuel cell, PVA

\begin{abstract}
ABSTRAK
Penggunaan polimer alam sebagai membran pada Direct Methanol Fuel Cell (DMFC) berbasis kitosan dikembangkan karena lebih ramah lingkungan dan memiliki stabilitas termal tinggi, namun konduktivitas protonnya rendah. Lempung dari Babakan Madang dengan kandungan Si 50\% diharapkan dapat meningkatkan konduktivitas proton serta memperbaiki karakteristik membran polimer tersebut. Sintesis membran berbasis kitosan/PVA dilakukan dengan penambahan variasi berat lempung sebesar 0,3, 0,6 dan 0,9 g. Pengujian dengan Fourier Transform Infrared (FTIR) mengkonfirmasi terbentuknya membran kompositkitosan/PVA/lempung. Analisis morfologi dengan Scanning Electron Microscope (SEM) menunjukkan bahwa terdapat butiran-butiran lempung yang terdispersi pada membran. Hasil pengujian dengan Electrochemical Impedance Spectroscopy (EIS)menunjukkan nilai konduktivitas proton tertinggi adalah membran dengan penambahan lempung $0,6 \mathrm{~g}$ sebesar $6,96 \times 10^{-7} \mathrm{~S} / \mathrm{cm}$. Swelling air membran yang dihasilkan pada ketiga membran cenderung tinggi, dengan nilai terkecil $56,69 \%$ pada membran dengan penambahan lempung 0,9 gram. Hasil pengujian swelling metanol sebesar 346,11\% untuk membran dengan penambahan 0,6 gram lempung.
\end{abstract}

Kata kunci : membran penukar ion, kitosan, fuel cell, PVA

\section{PENDAHULUAN}

Sel bahan bakar yang memanfaatkan metanol sebagai sumber bahan bakar salah satunya adalah DMFC. DMFC yang dikembangkan hingga saat ini masih memiliki kekurangan dari sisi kinerjanya, antara lain terkait pada bagian proton exchange membrane atau proton electrolyte membrane (PEM) yang digunakan. Nafion ${ }^{\circledR}$ merupakan salah satu membran yang sering digunakan dalam sel bahan bakar, sehingga mudah ditemukan di pasaran karena memiliki konduktivitas proton yang tinggi yaitu $0,1 \mathrm{~S} / \mathrm{cm}$ di bawah $100^{\circ} \mathrm{C}$ dan persentase penyerapan air yang rendah sebesar $19 \%$. Walaupun membran tersebut sering diaplikasikan pada pembuatan reaktor fuel cell, akan tetapi masih memiliki beberapa kelemahan diantaranya kemampuan degradasi, korosif, suhu operasi yang dalam aplikasinya tidak bisa melebihi 
suhu $80^{\circ} \mathrm{C}$, serta permeabilitas metanol yang masih perlu diturunkan, yaitu sebesar $4,9 \times 10^{-8} \mathrm{~cm}^{2} / \mathrm{s}$ (Suka, 2010).

Jenis membran lain yang memungkinkan dapat diaplikasikan adalah membran berbasis kitosan. Stabilitas termal yang cukup tinggi merupakan salah satu karakteristik membran berbasis kitosan, namun membran tersebut masih memiliki kapasitas penukar kation yang rendah. Material bermuatan dapat disintesis dari membran berbasis kitosan yang dimodifikasi agar menghasilkan membran polimer elektrolit. Untuk meningkatkan sifat membran seperti konduktivitas proton, stabilitas termal, derajat pengembangan (swelling degree) air dan permeabilitas metanol, dapat dilakukan dengan cara modifikasi secara kimiawi. Beberapa penelitian telah dilakukan, diantaranya penambahan material grafin oksida (Julian, 2016); penambahan material silika (Siniwi, 2014), dan memodifikasi gugus fungsi yang berperan dalam peningkatan konduktivitas proton dengan sulfonasi (Rahmadani, 2014), fosforilasi (Wafiroh, 2016), substitusi enzimatik, pembentukan basa Schiff dan khelasi logam, proses perpanjangan rantai (kopolimerisasi cangkok dan crosslink) serta proses depolimerisasi, baik secara kimia, fisika maupun enzimatik (Kaban, 2009).

Pembuatan membran kitosan sering terkendala akan sifat fisiknya yang memiliki elastisitas yang rendah. Oleh karena itu, untuk mengurangi elastisitasnya, material lain sering dimanafaatkan ditambahkan dalam kitosan. Salah satu bahan yang sering dikombinasikan dengan kitosan adalah Polivinil alkohol (PVA). Titik leleh PVA pada suhu $228-256^{\circ} \mathrm{C}$ merupakan salah satu alasan dalam pertimbangan suhu operasi membran yang tinggi. Interaksi PVA dengan air memungkinkan peristiwa swelling akibat adanya gugus aktif dari PVA berupa $\mathrm{OH}$, yang memungkinkan material bersifat hidrofilik. Sifat mekanik material kitosan yang baik jika ditambahkan dengan PVA, maka sifat mekaniknya meningkat (Fajarwati, \& Nita, 2012). Keterbatasan pemanfaatan membran berbasis kitosan lainnya adalah rendahnya konduktivitas proton. Salah satu metode untuk mengatasi hal tersebut adalah modifikasi dengan material anorganik, salah satunya menggunakan oksida yang terdapat dalam lempung atau tanah liat. Lempung dipilih karena murah dan mudah untuk memperolehnya. Lempung sebagai material organik dlam hal ini, berfungsi sebagai material pengisi (filler), yang diharapkan dapat meningkatkan sifat-sifat membran, khusunya sifat mekanik dan konduktivitas protonnya. Filler anorganik seperti $\mathrm{TiO}_{2}$, $\mathrm{SiO}_{2}, \mathrm{CaO}$, zeolit dan lempung dapat meningkatkan kapasitas tukar kation (KTK), stabilitas termal, serta mengurangi swelling degree membran Nafion (Zakil, 2016).

Peningkatan performance membran dapat dihasilkan salah satunya dengan mensintesis membran komposit. Penelitian dengan pemanfaatan material $\mathrm{TiO}_{2}$ sebagai filler menunjukkan bahwa penambahan $\mathrm{TiO}_{2}$ dapat meningkatkan konduktivitas, stabilitas membran dan menurunkan swelling degree pada membran (Hakim, 2012). Penelitian lain dilakukan dengan penambahan material $\mathrm{SiO}_{2}$ sebagai filler pada membran berbasis PVA sehingga meningkatkan konduktivitas, stabilitas membran dan menurunkan permeabilitas air dan etanol, dan memiliki stabilitas termal $130^{\circ} \mathrm{C}$ (Sik, 2006). Peristiwa swelling yang berlebihan dapat direduksi oleh material silika yang ditambahkan, sehingga kadar air lebih terkontrol, mengurangi permeabilitas metanol, stabilitas mekanik dan konduktivitas proton yang meningkat sebagai PEM untuk sel bahan bakar (Ulbricht, 2006).

Tujuan penelitian ini adalah mengetahui karakteristik PEM berbasis kitosan untuk meningkatkan konduktivitas dan karakteristik fisik membran penukar proton fuel cell dengan penambahan variasi massa lempung yang berasal dari Babaan Madang, Bogor.

\section{BAHAN DAN METODE}

\section{Bahan dan Alat}

Peenelitian menggunakan bahan berikut, antara lain, kitosan dengan derajat deasetilasi (DD) 82\%. Lempung berasal dari Desa Ciburial Kecamatan Karang Tengah, 
Babakan Madang, Bogor dengan andungan utama adalah kuarsa. Vanilin (Merck), Pyperidin(Merck), $\quad \mathrm{CH}_{3} \mathrm{COOH}$ (Merck), $\mathrm{NaOH}$ (Merck), $\mathrm{NaCl}$ (Merck), HCl(Merck), Etanol(Merck), Metanol(Merck),dan PVA(Merck).

Peralatan laboratorium sederhana yang digunakan yaitu seperangkat alat gelas, magnetic stirer, plat kaca pencetak membran, grinder, oven, dan neraca digital. Instrumen yang digunakan yaitu Spektrofotometer Fourier Transform-Infra Red (FT-IR) Shimadzu tipe IR Prestige 21, EIS (Electrochemical Impedance Spectroscopy) Autolab PGSTAT128N, SEM (Scanning Electron Microscope) Carl Zaiss Bruker, dan X-Ray Diffraction (XRD) tipe Maxima 7000 Shimadzu.

\section{Metode}

\section{Preparasi Kitosan}

Kitosan (DD 82\%) diblender kemudian disaring dengan ayakan 100 mesh. Kitosan yang lolos ayakan 100 mesh kemudian dikumpulkan dan disimpan dan dikarakterisasi dengan FTIR.

\section{Preparasi Lempung}

Tanah liat yang diperoleh dari Desa Ciburial, Karang Tengah, Kecamatan Babakan Madang, Kabupaten Bogor dilarutkan dalam akuades dengan perbandingan 1:1. Koloid yang terbentuk kemudian dibiarkan semalam sampai mengendap. Dua lapisan terbentuk, terdiri dari lapisan atas yang berupa air dibuang hingga didapatkan lempung dalam bentuk pasta. Pasta dioven pada suhu $150^{\circ} \mathrm{C}$ hingga kering. Lempung bersih yang kering dihaluskan dengan ayakan 100mesh.

\section{Sintesis Membran}

Sintesis membran komposit

Kitosan/PVA/lempung dilakukan dengan menggunakan variasi konsentrasi berat/berat $(\mathrm{w} / \mathrm{w})$ yaitu 0,$30 ; 0,60$ dan $0,90 \mathrm{~g}$. Yang selanjutnya, membran tersebut disebut sebagai membran 1, membran 2 dan membran 3 secara berturut-turut. 1,845 g PVA dilarutkan dalam asam asetat $2 \%$ diatas hot plate dengan diaduk magnetic stirrer menggunakan pemanasan pada suhu $90^{\circ} \mathrm{C}$ dengan kecepatan $700 \mathrm{rpm}$ hingga larut sempurna, kemudian ditambahkan lempung 0,30 g pada larutan PVA hingga lempung terdispersi tanpa suhu. Setelah itu, 1,646 g kitosan-vanilin ditambahkan ke dalam campuran sehingga berat total campuran 150 g. Campuran lalu diaduk hingga larut. Larutan kemudian dicetak diatas plat kaca dan dikeringkan pada suhu $60^{\circ} \mathrm{C}$ selama 6 jam. Langkah yang sama juga dilakukan untuk pembuatan membran dengan variasi tanah lempung 0,60 dan 0,90 g. Membran yang telah terbentuk dikarakterisasi dengan menggunakan instrumen FT-IR (Shimadzu tipe IRPrestige 21), dan SEM. Spesifikasi membran berupa swelling air, swelling metanol, konduktivitas proton diukur.

\section{HASIL DAN PEMBAHASAN}

\section{Karakterisasi Membran Kitosan/ PVA/ Lempung}

Membran diukur secara kualitatif dengan instrumen spektroskopi FT-IR pada bilangan gelombang antara $4.000-400 \mathrm{~cm}^{-1}$. Serapan pada daerah $3.000 \mathrm{~cm}^{-1}$ merupakan serapan dari rentangan $-\mathrm{OH}$ yang tumpang tindih dengan rentangan $-\mathrm{NH}$. Rentangan $\mathrm{CH}$ alifatik terlihat pada serapan $2.800 \mathrm{~cm}^{-1}$. Vibrasi rentangan $\mathrm{C}=\mathrm{N}$ ditunjukan pada serapan $1.625 \mathrm{~cm}^{-1}$ sedangkan vibrasi tekuk $-\mathrm{NH}$ terlihat pada serapan $1.580 \mathrm{~cm}^{-1}$. Serapan pada $1.517 \mathrm{~cm}^{-1}$ merupakan serapan dari deformasi protonasi dari gugus amino ($\mathrm{NH}_{3}{ }^{+}$). Rentangan tekuk C-H terlihat pada $1410 \mathrm{~cm}^{-1}$. Rentangan $\mathrm{C}-\mathrm{OH}$ dari gugus fenol ditunjukan pada puncak serapan 1.312 $\mathrm{cm}^{-1}$. Serapan kuat pada $1.125 \mathrm{~cm}^{-1}$ merupakan serapan rentangan $\mathrm{Si}-\mathrm{O}-\mathrm{Si}$ yang tumpang tindih dengan rentangan $\mathrm{C}-\mathrm{O}$. Pelemahan serapan pada daerah $3.700 \mathrm{~cm}^{-1}$ pada membran komposit yang merupakan serapan dari $\mathrm{Si}-\mathrm{OH}$ atau $\mathrm{AlOH}$ pada lempung, dikarenakan terbentuknya ikatan hidrogen antara gugus $-\mathrm{OH}$ yang terikat dengan atom $\mathrm{Si}$ atau $\mathrm{Al}$ dengan gugus $-\mathrm{OH}$ dari $\mathrm{KV}$ dan PVA atau gugus amino $\left(-\mathrm{NH}_{2}\right)$ dari $\mathrm{KV}$. 


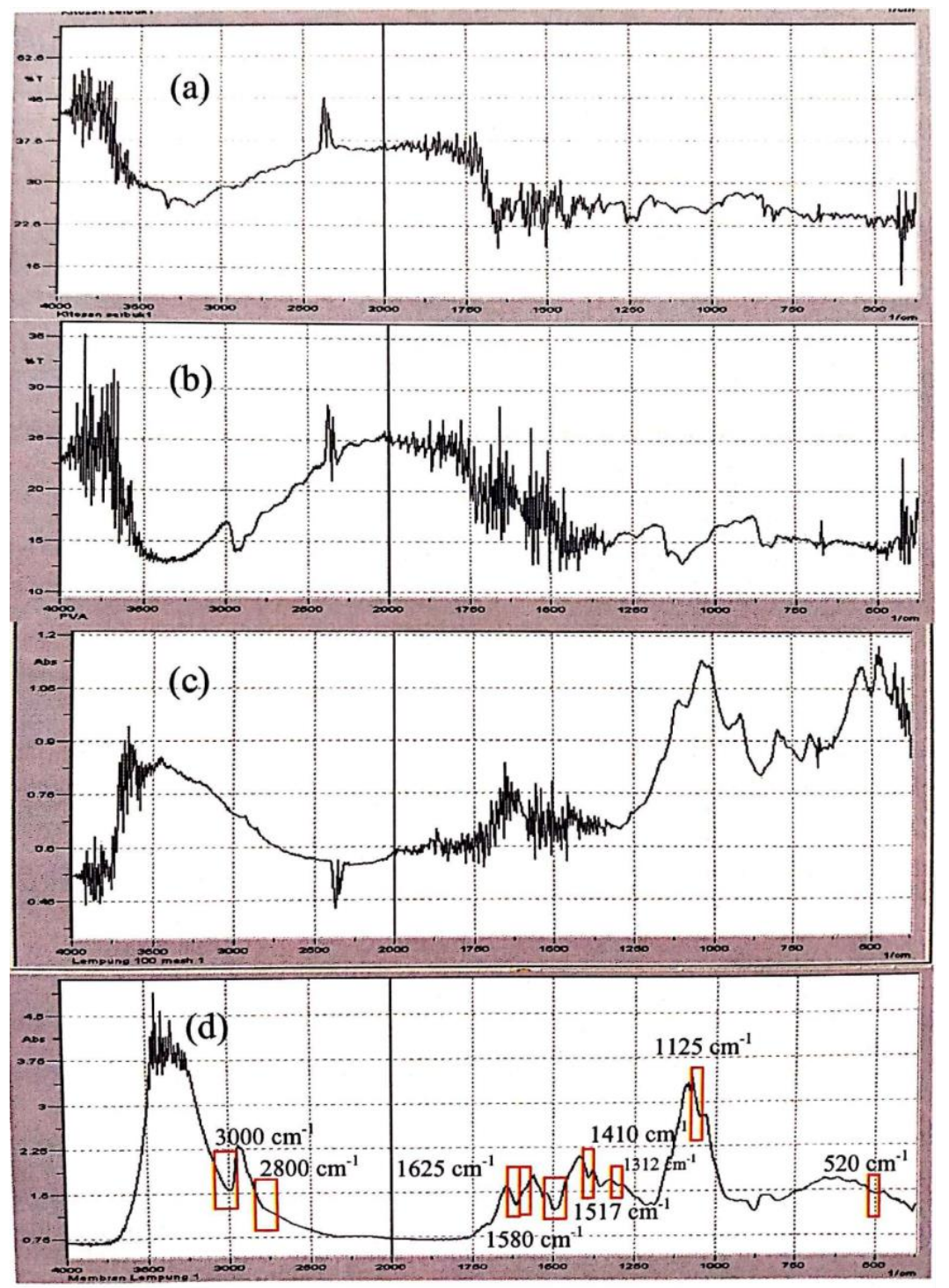

Gambar 1. Spektra FTIR (a)KV, (b)PVA, (c)lempung dan (d)membran KV/PVA/Lempung

\section{Uji SwellingAir}

Uji Swelling Air/Water Uptake dibutuhkan untuk menguji kemampuan penyerapan air oleh membran, sebagai ukuran seberapa kuat air dapat terserap oleh membran. Air yang terkungkung dalam membran fuel cell dapat berperan sebagai media transpor proton $\mathrm{H}^{+}$pada kadar tertentu, yang terkait dengan konduktivitas proton, sehingga dapat digunakan untuk memperkirakan kinerja membran, saat terjadi perubahan membran dari kondisi awalnya. Air yang terserap dalam membran komposit tersebut memang berrfungsi sebagai media transfer proton, tetapi jika membran terlalu tinggi persen swellingnya, membran akan cenderung rapuh. Data yang diperoleh menunjukkan bahwa semakin bertambahnya persentase lempung yang terkandung pada membran, persentase swelling membran tersebut juga semakin tinggi, karena penambahan lempung yang mengandung silika meningkatkan pengikatan membran terhadap partikelpertikel air. Penambahan lempung diharapkan berfungsi untuk meningkatkan konduktivitas ionik pada membran tersebut, walaupun sampai pada penambahan persentase tertentu, lempung mempunyai sifat higroskopis yang dapat mengikat tambahan air. Hasil yang didapatkan ini konsisten dengan beberapa penelitian yang terdahulu (Hande, 2011). 
Kenaikan swelling air pada membran tipe 1 dan 2 menunjukkan peningkatan yang signifikan dari $69,08 \%$ menjadi $93,03 \%$ dengan penambahan lempung sebesar 0,3 dan 0,6 gram berturutturut tetapi terdapat penurunan persentase pada membran tipe 3 dengan penambahan lempung 0,9 gram tipe 3 , nilai swelling menurun menjadi $56,69 \%$ (Gambar 2). Hal ini disebabkan karena lempung yang terdispersi pada membran 3 sudah melebihi kapasitas maksimal, sehingga tidak dapat terdispersi dengan baik, berbeda dengan membran tipe 1 dan 2 . Hal lain yang memungkinkan mengakibatkan hal tersebut adalah ukuran partikel lempung yang besar, sehingga kapasitas membran untuk medispersi lempung sudah melampaui kapasitasnya.

Membran KV/PVA/Lempung dengan penambahan lempung 0,9 gram (tipe 3) memiliki nilai water sweeling yang paling rendah dengan nilai 56,69\%, sedangkan membran dengan persentase paling tinggi adalah membran dengan penambahan lempung 0,6 gram (tipe 2), sebesar 93,03\%. Saat membran bekerja dalam sel bahan bakar, membran yang terhidrasi memungkinkan membran dapat menghantarkan proton. Namun, kadar air yang terlalu tinggi akan mengakibatkan membran menjadi terlalu basah, sehingga kinerja dari sel bahan bakar menjadi terganggu karena saluran ion yang diperbesar oleh partikel air pada membran (Julian, 2016).

\section{Uji SwellingMetanol}

Daya serap membran terhadap metanol diukur dengan uji swelling metanol atau methanol uptake. Pada aplikasi direct methanol fuel cell (DMFC), permeabilitas metanol pada membran dapat dikaji dari daya serap membran yang berkaitan dengan methanol crossover. Derajat permeabilitas metanol yang semakin tinggi mnenyebabkan membran tersebut kurang baik untuk diaplikasikan. Besarnya tingkat permeabilitas metanol berkaitan dengan methanol crossover dalam aplikasi direct methanol fuel cell (DMFC). Sejumlah bahan bakar yang digunakan dapat merembes akibat methanol crossover dan laju reaksi di katoda yang melambat dapat menurunkan besaran voltase sel secara keseluruhan. Semakin besar konsentrasi silika yang ditambahkan, swelling metanol semakin bertambah. Hal ini dikarenakan metanol bersifat polar, sehingga dapat tertahan oleh karena keberadaan silika yang bersifat higroskopik dan mempunyai luas permukaan yang lebih besar (Hartanto et al., 2007). Membran tipe 3 merupakan membran komposit yang mengalami penambahan massa paling rendah, sebesar $227,17 \%$. Sedangkan membran tipe 2 merupakan membran komposit yang memiliki persentase paling tinggi, sebesar $346,11 \%$ (Gambar 3). Hasil swelling metanol memiliki pola yang sebanding dengan hasil swelling air yaitu nilai swelling mengalami kenaikan signifikan pada tipe 1 dan 2 tetapi mengalami penurunan pada tipe 3.

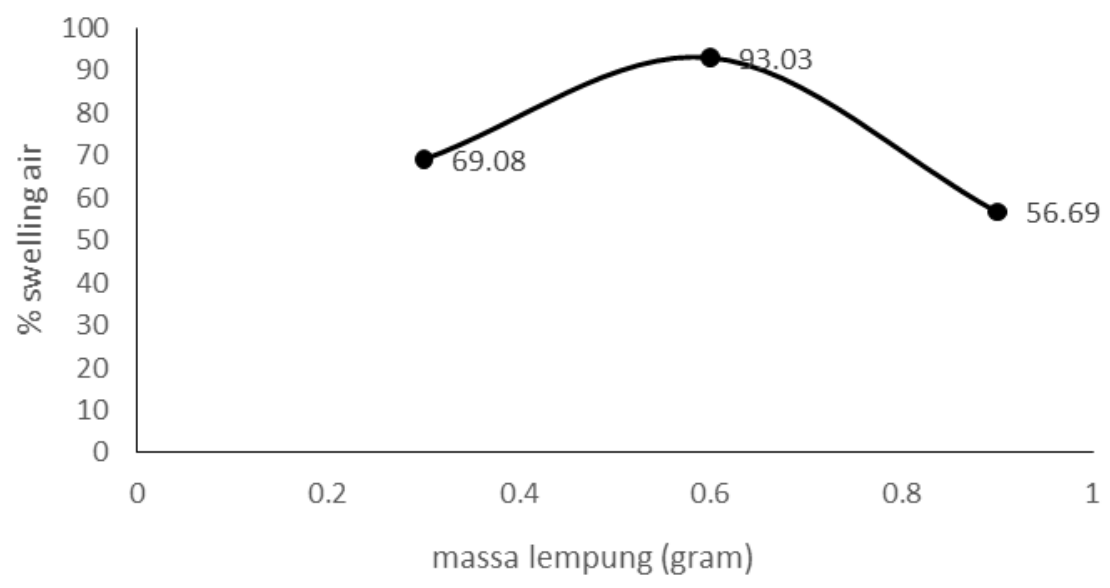

Gambar 2. Grafik Hasil Pengukuran Swelling Air 


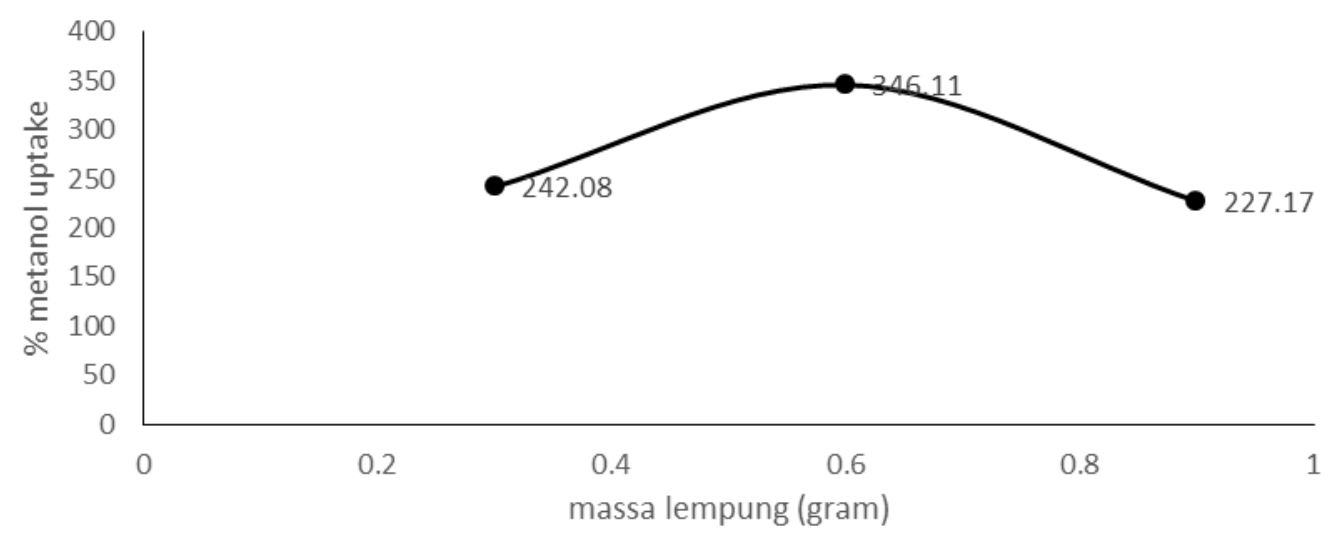

Gambar 3. Hasil Uji Swelling Metanol

Hasil uji swelling terhadap metanol lebih besar daripada hasil uji swelling terhadap air. Hal tersebut dikarenakan adanya penyerapan metanol yang sangat besar sehingga hasil swelling yang dihasilkan terhadap metanol lebih tinggi dibandingkan uji swelling terhadap air. Hal ini dapat dijelaskan bahwa metanol dapat teradsorp oleh silika yang terdispersi pada membran KV/PVA/Lempung sehingga sebagian besar metanol tidak melewati membran. Pori pada membran dapat tertutup oleh silika sehingga metanol dapat berpindah walaupun melalui pori membran yang sangat kecil. Metanol dapat tertahan oleh pori pada silika membran sehingga semakin tinggi swelling metanol diharapkan permeabilitas metanolnya akan semakin kecil.

\section{Konduktivitas Proton}

Efektivitas kinerja DMFC ditentukan dari nilai konduktivitas proton suatu membran. Konduktivitas proton yang tinggi mengindikasikan kualitas membran penghantar proton yang baik, yang artinya efisiensi sistem sel bahan bakarnya tinggi. Konduktivitas proton suatu membran dapat didefinisikan sebagai kemampuan suatu proton yang bergerak dari katoda menuju anoda. Konduktivitas ionik suatu membran diukur dengan menggunakan Electrochemical Impedance Spectroscopy (EIS) yang dilakukan dalam keadaan terhidrasi. Pada penelitian ini, uji konduktivitas ionik dilakukan untuk mengetahui kemampuan migrasi ion-ion $\mathrm{H}^{+}$ dalam membran elektrolit dengan menggunakan EIS.

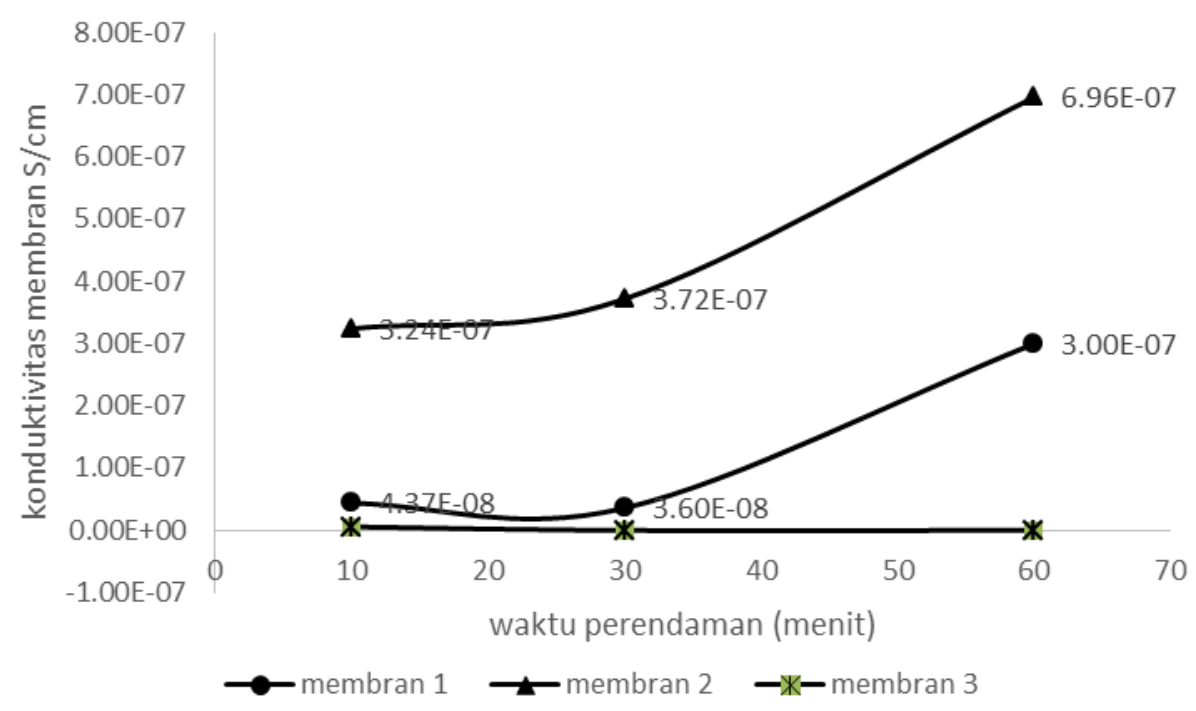

Gambar 4. Grafik Konduktivitas Proton Membran 


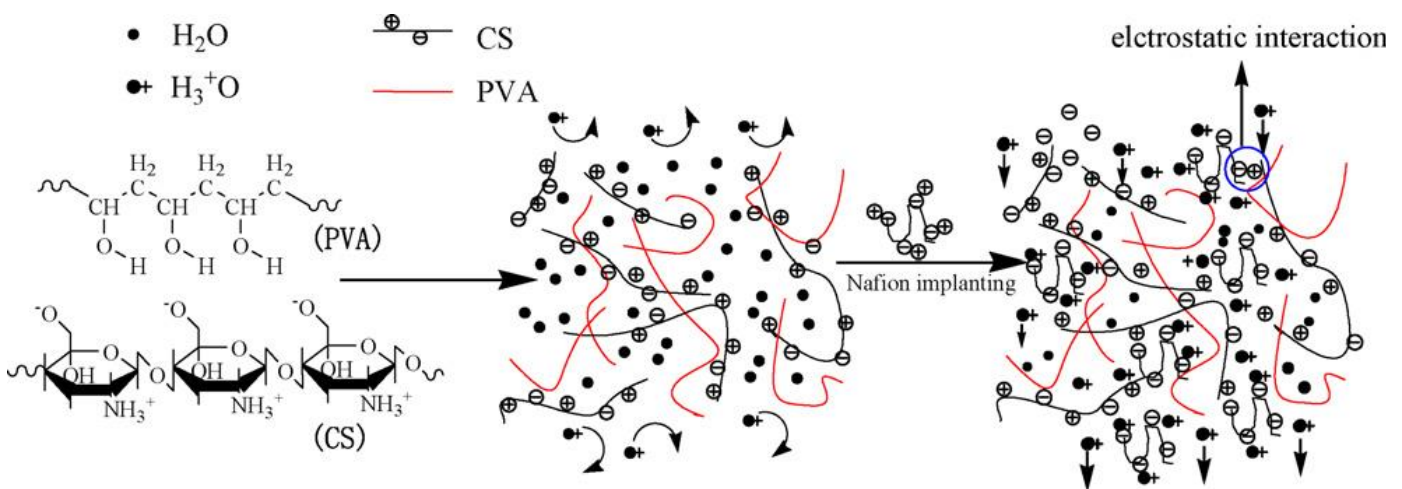

Gambar 5. Ilustrasi Grafis Struktur Membran Kitosan-PVA (Zhang, 2009)

Konduktivitas proton meningkat seiring meningkatnya komposisi lempung yang ditambahkan pada membran. Hal ini menunjukkan bahwa penambahan silika yang masuk ke dalam matriks polimer mempengaruhi besarnya konduktivitas proton $(\mathrm{Li}, 2011)$. Selain itu, faktor lain seperti jumlah gugus ionik dan kecepatan hidrasi juga mempengaruhi performa membran (Pereira et al., 2008). Berdasarkan kecepatan hidrasi pada waktu perendaman, semakin lamanya waktu perendaman membran dalam aqua demineralisasi (DM), nilai konduktivitas membran semakin bertambah hingga waktu perendaman selama 60 menit. Berbeda halnya dengan membran 3, konduktivitas membrannya tidak mengalami kenaikan seiring dengan bertambahnya waktu perendaman, dan nilai konduktivitas membran tersebut jauh lebih kecil dibandingkan dengan membran tipe 1 dan 2. Hal ini dapat dijelaskan bahwa pada menit awal, molekul air belum tersebar secara merata sehingga diperlukan sedikit waktu agar molekul air dapat tersebar secara optimal dikarenakan bertambahnya komposisi kitosan yang bersifat hidrofobik pada membran.

Semakin tinggi komposisi lempung yang bersifat hidrofilik, molekul air dapat semakin cepat menghidrasi membran dan tersebar secara merata. Konduktivitas tertinggi dimiliki oleh membran tipe 2 dengan nilai $6,96282 \times 10^{-7} \mathrm{~S} / \mathrm{cm}$ dengan waktu perendaman 60 menit. Nilai tersebut sama-sama nilai yang belum diharapkan sebagai membran dengan konduktivitas proton yang baik, penelitian dengan membuat membran polistiren termodifikasi silika yaitu $7 \times 10^{-6} \mathrm{~S} / \mathrm{cm}$ (Suka et al., 2010). Meskipun membran tipe 2 mempunyai nilai konduktivitas tertinggi tetapi, membran ini mempunyai nilai swelling air yang besar yaitu 93,03\% hal tersebut kurang memenuhi kriteria digunakan sebagai membran pada DMFC. Salah satu parameter membran yang sesuai dengan aplikasi reaktor fuel cell, tidak melebihi kadar swelling air sebesar 50\%. Suatu membran DMFC memiliki swelling air yang baik tidak lebih dari 50\% (Siniwi, 2014). Jika konduktivitas proton meembrn hasil penelitian tersebut dibandingkan dengan konduktivitas membran Nafion ${ }^{\circledR}$ dengan nilai sebesar 0,1 $\mathrm{S} / \mathrm{cm}$, maka hasil konduktivitas proton membran KV/PVA/Lempung masih sangat kecil. Nilai konduktivitas ionik membran untuk aplikasi DMFC dapat diklasifikasikan menjadi dua kriteria, yaitu nilai konduktivitas ionik besar dengan rentang nilai $10^{-1}-10^{-2} \mathrm{~S} / \mathrm{cm}$ dan nilai konduktivitas ionik kecil dengan rentang nilai sebesar $10^{-}$ 3 - $10^{-5} \mathrm{~S} / \mathrm{cm}$ (Anita, 2006; Yohan, 2005).

\section{Uji Scanning Electron Microscopy(SEM)}

Struktur morfologi membran KV/PVA/Lempung dianalisis dengan Scanning Electron Microscopy (SEM), perbesaran 50 kali dan perbedaan tegangan $20 \mathrm{kV}$. Membran yang dianalisis adalah membran tipe 2 yang memiliki konduktifitas proton yang tinggi. 


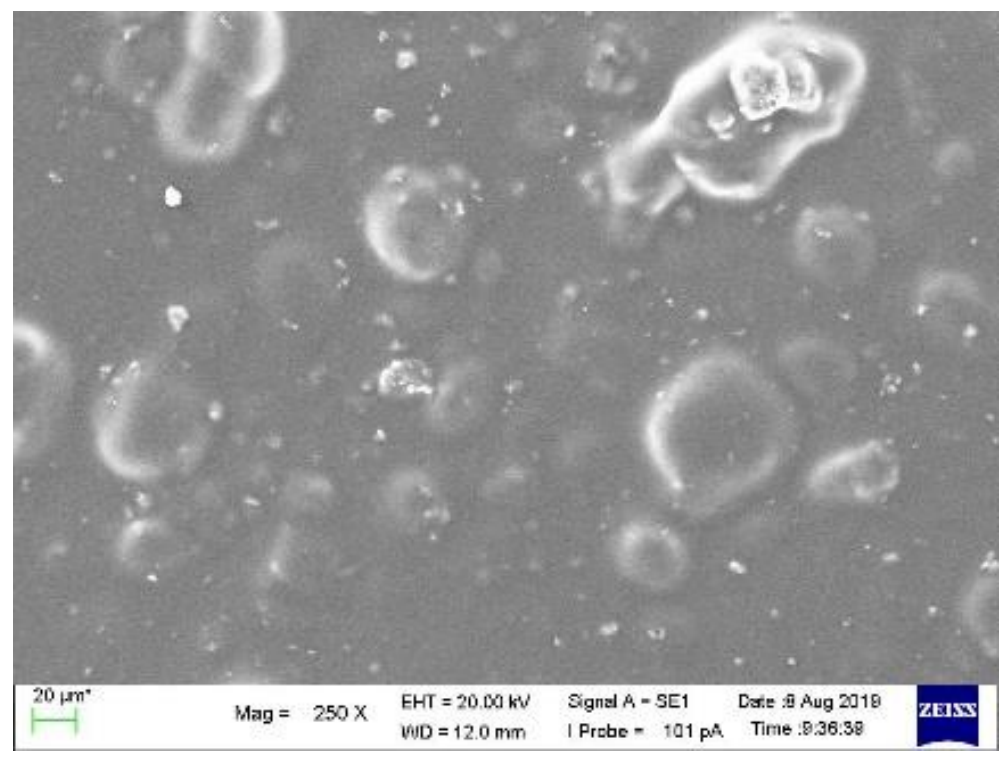

Gambar 6. Morfologi Membran Kitosan/PVA/lempung

Penambahan massa silika yang terkandung pada lempung mengakibatkan pembentukan pori-pori dengan ukuran yang kecil dan membentuk struktur jala berupa rongga-rongga pada permukaan membran. Muatan negatif gugus $\mathrm{OH}^{-}$dari kitosan yang bereaksi dengan silika menyebabkan terbentuknya ronga-rongga yang sangat rapat akibat dari ditambahkannya silika. Jika dilihat dari homogenitas, lempung menghasilkan membran komposit yang kurang homogen. Hal ini dikarenakan partikel lempung yang kurang halus menyebabkan lempung tersebut kurang larut dalam larutan cetak, sehingga pada saat larutan di cetak pada media plat kaca, lempung dalam larutan terdistribusi tidak merata. Berdasarkan morfologinya, terbentuk bulatan berwarna putih di permukaan membran disebabkan terbatasnya kelarutan polimer kitosan atau PVA. Bercak tersebut merupakan kitosan yang belum larut sempurna dengan pelarutnya yaitu asam asetat $2 \%$ yang menyebabkan homogenitas larutan kurang sempurna, sehingga masih berbentuk gumpalan-gumpalan, atau ada debu yang menempel pada saat pencetakan dan pengeringan membran. Kemungkinan yang lain adalah dikarenakan adanya gelembung udara yang terdistribusi di antara material penyusunannya. Untuk kriteria membran yang baik, pori-pori partikel yang semakin rapat dan teratur maka semakin baik membran tersebut untuk proses filtrasi (Muljani, 2018). Hasil serupa juga ditunjukkan oleh penelitian Priyadi (2012) dengan pengujian morfologi membran menggunakan mikroskop dengan pembesaran 1000 kali bahwa membran komposit polistirena (PST) tanpa penambahan lempung menghasilkan membran dengan morfologi yang cukup homogen/rata, meskipun masih ada bercakbercak. Kemungkinan bercak-bercak tersebut merupakan PST yang belum larut sempurna dengan pelarutnya dimetil asetamida (DMAc), sehingga masih berbentuk gumpalan-gumpalan dan pada penambahan lempung dalam membran komposit PST menghasilkan membran komposit yang kurang homogen (Priyadi, 2012).

\section{KESIMPULAN}

Membran Kitosan/PVA/Lempung telah berhasil disintesis. Penambahan lempung meningkatkan koduktivitas proton dan menurunkan permeabilitas metanol berdasarkan hasil swelling metanol. Hasil membran dengan hasil konduktivitas proton yang tertinggi adalah membran tipe 2 , penambahan massa lempung $0,6 \mathrm{~g}$ sebesar $6,96 \times 10^{-7} \mathrm{~S} / \mathrm{cm}$, Untuk swelling air yang 
cukup baik adalah membran tipe 3 dengan penambahan lempung 0,9 g yaitu $56,69 \%$ dan membran tipe 2 dengan penambahan lempung $0,6 \mathrm{~g}$ untuk swelling metanol sebesar346,11\%.

\section{UCAPAN TERIMA KASIH}

Penelitian ini telah didanai dengan program Penelitian Kompetitif Nasional dengan Skim Penelitian Dosen Pemula (PDP) tahun pelaksanaan 2019 sesuai kontrak nomor: 2656/L4/PP/2019 tanggal 19 Maret 2019 oleh Kementrian Riset, Teknologi dan Pendidikan Tinggi Republik Indonesia.

\section{DAFTAR PUSTAKA}

Hande, V. R., Rath, S. K., Rao, S., \& Patri, M. (2011). Cross-linked sulfonated poly ( ether ether ketone ) ( SPEEK )/ reactive organoclay nanocomposite proton exchange membranes ( PEM ). Journal of Membrane Science, 372(12), 40-48.

Fajarwati, I., N. Kusumawati. (2012). Appliance In Waste Rhodamin-B Separation. UNESA Journal of Chemistry, 1(2), 31-38.

Julian, J., Santoso, E. (2016). Sintesis Dan Karakterisasi Proton Exchangemembrane KitosanNanosilika. Jurnal Sains dan Seni ITS, 4 (2), 2337-2343

Siniwi, W.T. (2014). Sintesis Dan Karakterisasi Proton Exchange Membrane Kitosan-Nanosilika. (Skripsi). Universitas Negeri Semarang

Li, X. J., Ke, C. C., Qu, S. G., Li, J., Shao, Z. G. \& Yi, B. L.. (2011). High Temperature PEM Fuel Cells Based on Nafion/SiO2 Composite Membrane. Energy Storage in the Emerging Era of Smart Grids, China: InTech
Muljani, S., Kusuma, K. A., Nofitasari, L., \& Amalia, A. R. (2018). Sintesis Membran Kitosan Silika Dari Geothermal Sludge. Jurnal Teknik Kimia, 13(1): 22-26.

Pereira, F., Vallé, K., Belleville, P., Morin, A., Lambert, S., \& Sanchez, C. (2008). Advanced Mesostructured Hybrid Silica - Nafion Membranes for HighPerformance PEM Fuel Cell. Journal of Chem Material, 229(9), 1710-1718.

Rahmadani, S. (2014). Membran komposit polisulfon tersulfonasi- zeolit untuk aplikasi DMFC (Skripsi). Institut Pertanian Bogor, Bogor.

Hakim, A.R., Purbasari, A., Djoko, T., \& Listiani, E. (2012). Composite sPEEK with Nanoparticles for Fuel Cell Applications. Proceeding of International Conference On Chemical and Material Engineering, 1-11.

Kim, D.S., Yun, T.I, Seo, M.Y.,Cho, H.I., Lee, Y.M., Nam, S.Y., and Rhim, J.W. (2006). Preparation of ion-exchange membranes for fuel cell based on crosslinked PVA / PSSA _ MA / silica hybrid,. Desalination. 200, 634-635.

Suka, I. G., Simanjuntak, W., Dewi, L. (2010). Pembuatan Membran Polimer Elektrolit Berbasis Polistiren Akrilonitril ( SAN ) untuk Aplikasi Direct Methanol Fuel Cell. Jurnal Natur Indonesia, 13(65), 1-6.

Anita, H. \& Desriana, T.U. (2006). Mempelajari pengaruh pencampuran (Blending) PEEK tersulfonasi dengan polisulfon untuk Aplikasi Membran Elektrolit. (Laporan Penelitian). Jurusan Teknik Kimia Fakultas Teknologi Industri. Institut Teknologi Indonesia, Tangerang.

Ulbricht, M. (2006). Advanced functional polymer membranes. Polymer, 47(7), 2217-2262. 
Wafiroh, S., Suyanto, S., \& Yuliana, Y. (2016). Pembuatan Dan Karakterisasi Membran Komposit Kitosan- Sodium Alginat Terfosforilasi Sebagai Proton Exchange Membrane Fuel Cell (PEMFC). Journal Kimia Riset, $1(1), 14-21$.

Kaban, J. (2009). Modifikasi Kimia dari Kitosan dan Aplikasi Produk yang Dihasilkan (Skripsi). Universitas Sumatera Utara, Medan.

Zakil, F. A., Kamarudin, S. K., \& Basri, S. (2016). Modified Nafion membranes for direct alcohol fuel cells: An overview. Renewable and Sustainable Energy Reviews, 65,841-852.

Zhang, Y., Cui, Z., Liu, C., Xing, W., Zhang, J. (2009)Implantation of Nafion ${ }^{\circledR}$ ionomer into polyvinyl alcohol/chitosan composites to form novel proton-conducting membranes for direct methanol fuel cells. Journal of Power Sources, 194, 730-736.

Priyadi. (2012). Membran Komposit Polistirena Berpengisi Lempung Sebagai Membran Elektrolit Untuk Aplikasi Sel Bahan Bakar (Skripsi). Universitas Negeri Sebelas Maret, Surakarta. 